\title{
IMPLEMENTASI MODEL PEMBELAJARAN ADVANCE ORGANIZER BERBANTUAN MACROMEDIA FLASH UNTUK MENINGKATKAN KEMAMPUAN KOMUNIKASI MATEMATIS SISWA KELAS XI SMA PAB 8 SAENTIS
}

\author{
Togi, Mei Lastiar Nababan \\ Fakultas Matematika dan Ilmu Pengetahuan Alam, Universitas Negeri Medan \\ E-mail :togi17@gmail.com \\ Email: meilastiarnababan@yahoo.co.id
}

\begin{abstract}
ABSTRAK
Penelitian ini bertujuan untuk (1) Mengetahui apakah melalui model pembelajaran advance organizer berbantuan macromedia flash dapat meningkatkan kemampuan komunikasi matematis siswa (2) Mengetahui peningkatan hasil belajar siswa setelah diterapkan model pembelajaran advance organizer berbantuan macromedia flash. Jenis penelitian ini adalah penelitian tindakan kelas. Subjek penelitian yaitu siswa yang bejumlah 30 orang. Objek penelitian adalah penerapan model advance organizer berbantuan macromedia flash untuk meningkatkan kemampuan komunikasi matematis siswa pada materi program linier. Penelitian ini terdiri dari dua siklus, dimana diakhir setiap siklus diberikan tes kemampuan komunikasi matematis untuk mengetahui kemampuan komunikasi matematis siswa. Berdasarkan hasil tes kemampuan awal yang dilakukan sebelum tindakan, diketahui tingkat kemampuan penalaran matematis siswa sangat rendah dengan nilai rata-rata kelas 47,55 dengan jumlah siswa yang mencapai KKM sebanyak 6 orang (20\%) dari jumlah siswa. Setelah pemberian tindakan pada siklus I, tingkat kemampuan komunikasi matematis siswa meningkat menjadi 64,14 dengan jumlah siswa yang mencapai KKM sebanyak 12 orang (40\%) dari jumlah siswa. Setelah pemberian tindakan sisklus II, rata-rata kemampuan komunikasi matematis siswa meningkat menjadi 78,75 dengan jumlah siswa yang mencapai KKM sebanyak 26 orang (86,67\%) dari jumlah siswa. Berdasarkan uraian-uraian di atas dapat disimpulkan komunikasi matematis siswa meningkat dengan menerapkan model advance organizer berbantuan macromedia flash pada materi program linier.
\end{abstract}

Kata Kunci : Advance Organizer, Komunikasi Matematis

\begin{abstract}
This study aims to (1) To know whether through advanced learning organizer model with macromedia flash can improve mathematical communication ability (2) to know improvement of student learning result after applied learning organizer model with macromedia flash. This type of research is a classroom action research. The subjects of the study were students which numbered 30 people. The object of research is the implementation of advanced organizer model with macromedia flash to improve students' mathematical

Togi, Mei Lastiar Nababan. Implementasi Model Pembelajaran Advance Organizer Berbantuan Macromedia Flash Untuk Meningkatkan Kemampuan Komunikasi Matematis Siswa Kelas Xi Sma PAB 8 Saentis. Jurnal Inspiratif, Vol. 3, No. 2 Agustus 2017.
\end{abstract}


communication ability in linear program material. This study consists of two cycles, where at the end of each cycle is given a test of mathematical communication ability to determine students' mathematical communication ability. Based on the results of initial ability tests conducted before the action, it is known the level of students' mathematical reasoning ability is very low with the average grade of 47.55 with the number of students who reach KKM as many as 6 people (20\%) of the number of students. After giving action on the first cycle, the level of students' mathematical communication ability increased to 64.14 with the number of students reaching KKM as many as 12 people (40\%) of the total students. After the second cycle, the average of students' mathematical communication ability increased to 78.75 with the number of students who reached KKM as many as 26 people (86.67\%) of the total students. Based on the above descriptions can be concluded mathematical communication of students increased by applying advanced organizer model with macromedia flash on linear program material

Keywords: Advance Organizer, Mathematical Communication

\section{Pendahuluan}

Matematika merupakan salah satu mata pelajaran di sekolah yang memegang peranan penting dalam membentuk siswa menjadi berkualitas, karena matematika sebagai salah satu sarana berpikir untuk mengkaji sesuatu secara logis dan sistematis. Seperti yang dikemukakan oleh Cornelius (Abdurrahman, 2009) bahwa : "Matematika merupakan sarana berfikir yang jelas dan logis, sarana untuk memecahkan masalah sehari-hari, sarana mengenal pola hubungan dan generalisasi pengalaman, sarana untuk mengembangkan kreativitas, serta sarana untuk meningkatkan kesadaran terhadap perkembangan budaya".

Banyak siswa yang memandang matematika sebagai bidang studi yang paling sulit, membosankan, bahkan menakutkan. Seperti yang dikemukakan oleh Abdurrahman (2009) bahwa: "Dari berbagai bidang studi yang diajarkan di sekolah, matematika merupakan bidang studi yang dianggap paling sulit oleh siswa, baik yang tidak berkesulitan belajar dan lebih-lebih bagi siswa yang berkesulitan belajar". Meskipun demikian, semua orang harus mempelajarinya karena merupakan sarana untuk memecahkan masalah kehidupan sehari-hari. Karena besarnya peranan matematika dalam proses peningkatan kualitas sumber daya manusia, maka upaya untuk meningkatkan kualitas pembelajaran matematika memerlukan perhatian yang serius.

Matematika sebagai salah satu pengetahuan mendasar yang sangat penting dan sangat dibutuhkan dalam perkembangan tehnologi saat ini, seperti yang dikemukakan Sihombing, W.L (2013) bahwa, "Tujuan pembelajaran matematika : (1) Melatih cara berpikir dalam bernalar dalam menarik kesimpulan, misalnya melalui kegiatan penyelidikan, eksplorasi, eksperimen, menunjujkkan kesamaan, perbedaan, konsisten, dan inkonsistensi, (2) Mengembangkan aktivitas kreatif yang menyebabkan imajinasi, instuisi, dan penemuan dengan mengembangkan

Togi, Mei Lastiar Nababan. Implementasi Model Pembelajaran Advance Organizer Berbantuan Macromedia Flash Untuk Meningkatkan Kemampuan Komunikasi Matematis Siswa Kelas Xi Sma PAB 8 Saentis. Jurnal Inspiratif, Vol. 3, No. 2 Agustus 2017. 
pemikiran divergen, orisinil, rasa ingin tahu, membuat prediksi, dan dugaan sementara, serta mencoba-coba, (3) Mengembangkan kemampuan pemecahan masalah, (4) Mengembangkan kemampuan menyampaikan informasi atau mengkomunikasikan gagasan antara lain melalui pembicaraan lisan, catatan, grafik, peta, diagram, dalam menjelaskan gagasan.”

Ada beberapa alasan tentang perlunya belajar dan menguasai matematika seperti yang dikemukakan oleh Cokrof (Abdurrahman, 2009) bahwa :Matematika perlu diajarkan kepada siswa karena : 1) Selalu digunakan dalam segi kehidupan; 2) Semua bidang studi memerlukan keterampilan matematika yang sesuai; 3) Merupakan sarana komunikasi yang kuat, jelas dan singkat; 4) Dapat digunakan untuk menyajikan informasi dalam berbagai cara; 5) Meningkatkan kemampuan berfikir logis, ketelitian, dan kesadaran keruangan; 6) Memberikan kepuasan terhadap usaha memecahkan masalah yang menantang.

Kemampuan komunikasi merupakan bagian yang sangat penting dalam belajar matematika, karena pembelajaran dilaksanakan melalui interaksi antara pendidik dan peserta didik. Dalam interaksi antara keduanya melalui proses komunikasi, baik secara lisan, maupun secara tulis. Kemampuan yang tidak kalah pentingnya yang harus dimiliki oleh siswa adalah kemampuan komunikasi matematis. Kemampuan yang akan diteliti untuk penelitian ini adalah kemampuan komunikasi tertulis. Salah satu alasan kemampuan menulis matematika harus ditingkatkan adalah karena menulis dapat meningkatkan taraf berpikir siswa kearah yang lebih tinggi Manzo(1995) (dalam Ansari, 2009:16). Menurut Barrody (1993) (dalam Ansari, 2009:16) ada beberapa keuntungan dari menulis (1) Summaries siswa disuruh merangkum pelajaran dengan bahasa sendiri. Kegiatan ini berguna karena dapat membantu siswa memfokuskan pada konsep-konsep kunci dalam suatu pelajaran. (2) Questions yaitu siswa disuruh membuat pertanyaan sendiri dalam tulisan. Kegiatan ini berguna membantu siswa merefleksikan pada focus yang mereka fahami. (3) Explanations yaitu siswa disuruh menjelaskan prosedur penyelesaian dan bagaimana menghindari kesalahan. (4) Definitions, yaitu mereka disuruh menjelaskan istilah-istilah yang muncul dalam bahasa mereka sendiri. Kegiatan ini berguna, karena dapat membantu siswa dalam berpikir tentang makna istilah dan menjelaskan pemahaman mereka terhadap istilah. (5) Reports, yaitu siswa disuruh, baik sebagai individu maupun sebagai suatu kelompok untuk menuliskan laporan. Kegiatan ini berguna untuk membantu pemahaman siswa, bahwa menulis adalah suatu aspek penting dalam matematika untuk menyelidiki topik-topik dan isu-isu dalam matematika dan kepribadiaan (Simanjuntak, M \& Surya, E. 2015).

Dalam proses pembelajaran, diperlukan usaha yang lebih keras dari guru mata pelajaran yang mampu menciptakan suasana yang menarik dan membuat para siswa lebih aktif dalam belajar dan berkomunikasi yaitu dengan menerapkan model pembelajaran advance

Togi, Mei Lastiar Nababan. Implementasi Model Pembelajaran Advance Organizer Berbantuan Macromedia Flash Untuk Meningkatkan Kemampuan Komunikasi Matematis Siswa Kelas Xi Sma PAB 8 Saentis. Jurnal Inspiratif, Vol. 3, No. 2 Agustus 2017. 
organizer. Model pembelajaran advance oraganizer adalah model pembelajaran yang bertujuan untuk mencapai belajar bermakna. Belajar bermakna (Dahar, 2006) merupakan "Suatu proses mengaitkan informasi baru pada konsepkonsep yang relevan yang terdapat pada struktur kognitif seseorang dan siswa diharapkan dapat mengomunikasikan konsep yang telah dimiliki atau ide baru kedalam pembelajaran. Hal ini dimaksudkan agar siswa dapat melihat adanya keterkaitan antara materi pelajaran yang telah mereka pelajari dengan informasi yang mereka dapatkan.

Oleh karena itu perlu adanya model pembelajaran yang dapat menjadi alat penghubung antara kemampuan komunikasi siswa dengan tujuan belajar bermakna. Alat penguhubung yang dimaksud adalah advance organizer. Advance organizer adalah model pembelajaran berdasarkan pada teori belajar bermakna. Model pembelajaran advance organizer memiliki tiga tahap kegiatan (Joyce, 2009), yaitu tahap pertama adalah presentasi advance organizer, tahap kedua adalah presentasi tugas pembelajaran atau materi pelajaran, tahap ketiga adalah penguatan struktur kognitif (Huda, Miftahul, 2014).

Pada pelaksanaanya, model advance organizer dapat dibantu berbagai sarana seperti peta konsep, bagan, diagram, media, dan sebagainya. Penerapan model pembelajaran advance organizer dalam pembelajaran matematika dapat menggunakan teknikteknik yang bervariatif (Aziz, 2008). Variasi yang dilakukan dalam penelitian ini yaitu menggunakan macromedia flash.
Macromedia flash adalah salah satu software yang mampu menyajikan pesan audio visual secara jelas kepada siswa.

Berdasarkan permasalahan yang telah diuraikan di atas, kemampuan komunikasi matematis siswa perlu ditingkatkan dan model advance organizer berbantuan macromedia flash sangat memungkinkan untuk menjadi penyelesaiannya.

\section{Metode Penelitian}

Penelitian ini dilakukan di SMA PAB 8 Saentis di kelas XI MIA-3. Adapun alasan peneliti memilih lokasi penelitian ini adalah dikarenakan di lokasi tersebut peneliti menemukan masalah. Penelitian dilaksanakan pada tahun ajaran 2017/2018. Subjek dalam penelitian ini adalah siswa kelas XI yang berjumlah 30 siswa. Objek dalam penelitian ini adalah kemampuan komunikasi matematika siswa dengan menerapkan model advance organizer pada pokok bahasan program linier. Jenis penelitian yang dilaksanakan adalah Penelitian Tindakan Kelas (PTK) atau Classroom Action Research (CAR) dengan menerapkan advance organizer, dilakukan dengan tujuan meningkatkan kemampuan komunikasi matematika siswa. Penelitian ini merupakan penelitian yang sifatnya kolaboratif karena adanya kerjasama antara peneliti dengan pendidik mata pelajaran matematika kelas XI SMA PAB 8 Saentis. Tes yang diberikan berbentuk tes uraian (essay test) yang bertujuan untuk mengetahui dan mengukur peningkatan kemampuan komunikasi siswa setelah mengikuti pembelajaran matematika dengan model

Togi, Mei Lastiar Nababan. Implementasi Model Pembelajaran Advance Organizer Berbantuan Macromedia Flash Untuk Meningkatkan Kemampuan Komunikasi Matematis Siswa Kelas Xi Sma PAB 8 Saentis. Jurnal Inspiratif, Vol. 3, No. 2 Agustus 2017. 
advance organizer. Sebelum digunakan terlebih dahulu peneliti memvalidkan tes tersebut berdasarkan para ahli sebagai validator. Observasi dilakukan dengan cara melakukan pengamatan selama proses pembelajaran berlangsung. Observasi dilakukan untuk mengetahui apakah proses pembelajaran dan kondisi belajar sudah terlaksana sesuai dengan Rencana Pelaksanaan Pembelajaran yang telah dirancang. Observasi yang dilakukan bersifat langsung dari awal sampai akhir tindakan dilaksanakan.

Angket digunakan untuk mengungkap respon siswa terhadap proses pembelajaran dengan menggunakan model advance organizer berbantuan macromedia flash dan perangkat pembelajaran dengan cara memberi tanda centang $(\sqrt{ })$ pada kolom yang tersedia untuk masing-masing pertanyaan yang diajukan. Angket ini diberikan pada siswa di akhir pokok bahasan.

Teknik Analisis Data

\section{Reduksi Data}

Setelah tes kemampuan komunikasi matematis siswa mengenai program linier diberikan, selanjutnya dikoreksi, dipelajari dan ditelaah untuk menggolongkan data dan mengorganisasikan jawaban siswa. Kegiatan reduksi ini bertujuan untuk melihat kesalahan jawaban siswa dan permasalahan yang dialami siswa dalam menyelesaikan soal dan tindakan apa yang dilakukan untuk memperbaiki kesalahan tersebut.

\section{Paparan Data}

Memaparkan data yang sistematis dan interaktif akan memudahkan pemahaman terhadap apa yang telah terjadi sehingga memudahkan penarikan kesimpulan atau menentukan tindakan yang akan dilakukan selanjutnya.

\section{Penarikan Kesimpulan}

Setelah dipaparkan, data kemudian disimpulkan. Kesimpulan yang diperoleh dijadikan dasar untuk pelaksanaan siklus berikutnya dan perlu tidaknya siklus berikutnya dilanjutkan atas dasar permasalahan yang ada. Siklus penelitian ini berhenti apabila dipenuhi target penelitian dalam arti penelitian ini berhasil.

Indikator keberhasilan dalam penelitian ini dapat dilihat dari:

1. Target pencapaian dalam siklus yaitu 85\% siswa dalam kelas memperoleh skor $\geq 65$

2. Guru dalam melaksanakan proses pembelajaran minimal berkategori baik, hal tersebut dilihat dari hasil persentase skor observasi aktivitas guru yaitu $\geq 2,2$

3. Persentase respon siswa terhadap pembelajaran melalui model discovery learning berbantuan geogebra memberi respon positif $\geq$ $80 \%$ (kategori positif)

\section{Hasil Penelitian}

Permasalahan I

Penelitian ini dilaksanakan di SMA PAB 8 Saentis di kelas XI MIA 3 dengan jumlah siswa 30 orang. Masalah dalam penelitian ini yaitu kemampuan komunikasi matematis siswa yang masih rendah yang terlihat pada hasil tes kemampuan awal yang diberikan peneliti kepada siswa kelas XI MIA 3 tersebut.

Dari hasil tes awal komunikasi matematis tertulis siswa didapati bahwa

Togi, Mei Lastiar Nababan. Implementasi Model Pembelajaran Advance Organizer Berbantuan Macromedia Flash Untuk Meningkatkan Kemampuan Komunikasi Matematis Siswa Kelas Xi Sma PAB 8 Saentis. Jurnal Inspiratif, Vol. 3, No. 2 Agustus 2017. 
kemapuan komunikasi matematis tertulis siswa masih rendah dengan nilai rata-rata kelas adalah 47,55. Berikut ini deskripsi hasil tes awal kemampuan komunikasi matematis siswa yang dapat dilihat pada tabel 1:

Tabel 1 Deskripsi Tingkat Penguasaan Siswa Pada Tes Awal

\begin{tabular}{|c|c|c|c|c|c|}
\hline No & $\begin{array}{c}\text { Tingkat } \\
\text { Penguasaan }\end{array}$ & $\begin{array}{c}\text { Skor } \\
\text { Standar }\end{array}$ & $\begin{array}{c}\text { Banyak } \\
\text { Siswa }\end{array}$ & $\begin{array}{c}\text { Persentase } \\
\text { Jumlah Siswa }\end{array}$ & Nilai Kualitatif \\
\hline 1 & $90 \%-100 \%$ & A & 1 & $3,33 \%$ & Sangat Tinggi \\
\hline 2 & $80 \%-89 \%$ & B & 0 & $0 \%$ & Tinggi \\
\hline 3 & $65 \%-79 \%$ & C & 8 & $26,67 \%$ & Sedang \\
\hline 4 & $55 \%-64 \%$ & D & 7 & $23,33 \%$ & Rendah \\
\hline 5 & $\leq 55 \%$ & E & 14 & $46,67 \%$ & Sangat Rendah \\
\hline
\end{tabular}

Diagram batang persentase tingkat kemampuan tes awal siswa pada pokok bahasan sistem persamaan linier dua variabel diatas sebagai berikut:

\section{Persentase Jumlah Siswa}

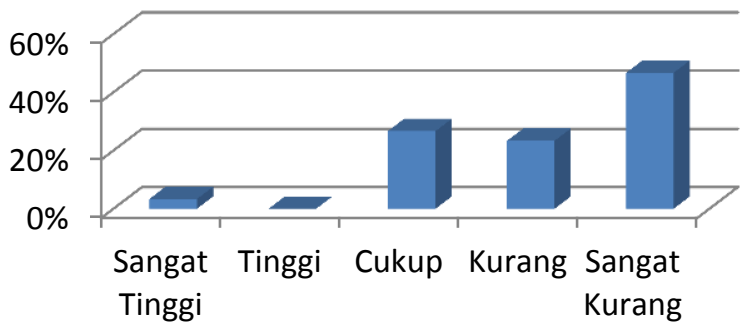

\section{Gambar 1 Diagram Tingkat Kemampuan Komunikasi Matematis}

Siswa Pada Tes Awal

Dari diagram diatas diperoleh bahwa siswa yang memiliki predikat A sebanyak 1 siswa, siswa yang memiliki predikat B sebanyak 0 siswa, siswa yang memiliki predikat $\mathrm{C}$ sebanyak 8 siswa, siswa yang memiliki predikat D sebanyak 7 siswa, dan siswa yang memiliki predikat E sebanyak 14 siswa. Sedangkan persentase ketuntasan klasikalnya adalah 20\%. Menyadari hal tersebut diperlukan suatu upaya untuk meningkatkan kemampuan komunikasi matematis siswa.
Upaya yang dapat dilakukan untuk meningkatkannya adalah dengan menerapkan model advance organizer berbantuan macromedia flash.

\section{Hasil Penelitian Siklus I}

Berdasarkan hasil jawaban siswa yang diberikan pada tes kemampuan komunikasi matematis siswa I diperoleh bahwa ada peningkatan kemampuan belajar dari tes awal. Dari hasil tes kemampuan komunikasi matematis siswa

Togi, Mei Lastiar Nababan. Implementasi Model Pembelajaran Advance Organizer Berbantuan Macromedia Flash Untuk Meningkatkan Kemampuan Komunikasi Matematis Siswa Kelas Xi Sma PAB 8 Saentis. Jurnal Inspiratif, Vol. 3, No. 2 Agustus 2017. 
I ini diperoleh 12 dari 30 orang siswa (40\%) telah mencapai ketuntasan belajar sedangkan 18 orang siswa lainnya $(60 \%)$ belum tuntas.

Tabel 2 Deskripsi Tingkat Penguasaan Siswa Pada Tes Kemampuan

Komunikasi Matematis I

\begin{tabular}{|c|c|c|c|c|c|}
\hline No & $\begin{array}{c}\text { Tingkat } \\
\text { Penguasaan }\end{array}$ & $\begin{array}{c}\text { Skor } \\
\text { Standar }\end{array}$ & $\begin{array}{c}\text { Banyak } \\
\text { Siswa }\end{array}$ & $\begin{array}{c}\text { Persentase } \\
\text { Jumlah Siswa }\end{array}$ & Nilai Kualitatif \\
\hline 1 & $90 \%-100 \%$ & A & 3 & $10 \%$ & Sangat Tinggi \\
\hline 2 & $80 \%-89 \%$ & B & 3 & $10 \%$ & Tinggi \\
\hline 3 & $65 \%-79 \%$ & C & 9 & $30 \%$ & Sedang \\
\hline 4 & $55 \%-64 \%$ & D & 7 & $23,33 \%$ & Rendah \\
\hline 5 & $\leq 54 \%$ & E & 8 & $26,67 \%$ & Sangat rendah \\
\hline
\end{tabular}

Diagram batang persentase tingkat ketuntasan tes kemampuan komunikasi matematis siswa pada siklus I yaitu :

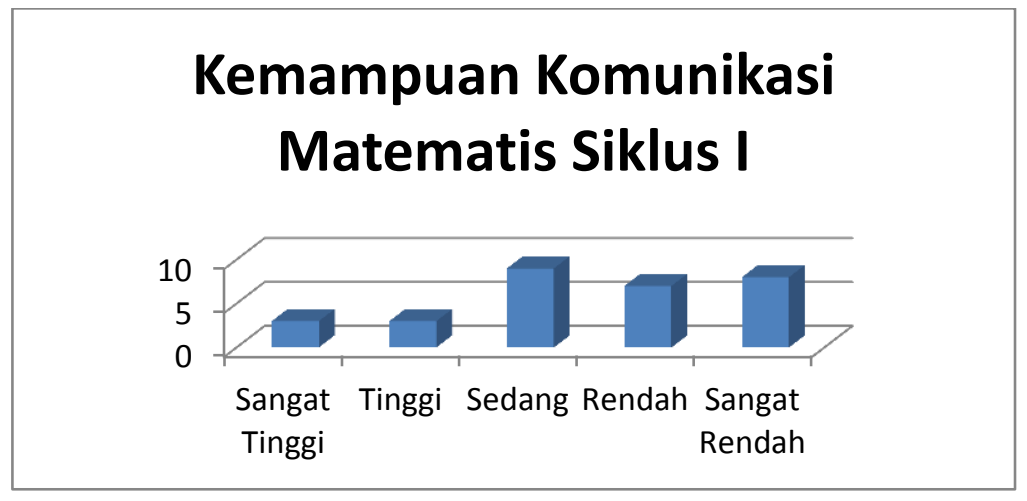

\section{Gambar 2 Diagram Tingkat Kemampuan Komunikasi Matematis Siswa Pada Tes Kemampuan Komunikasi Matematis I}

Dari diagram di atas diperoleh bahwa siswa yang memliki predikat A sebanyak 3 siswa, siswa yang memiliki predikat B sebanyak 3 siswa, siswa yang memliki predikat $\mathrm{C}$ sebanyak 9 siswa, siswa yang memiliki predikat D sebanyak 7 siswa, siswa yang memiliki predikat E sebanyak 8 siswa.
Karena belum tercapainya kriteria keberhasilan yang direncanakan yakni ketuntasan klasikal kelas minimal mencapai $\geq 85 \%$ maka penelitian ini berlanjut ke siklus II.

Togi, Mei Lastiar Nababan. Implementasi Model Pembelajaran Advance Organizer Berbantuan Macromedia Flash Untuk Meningkatkan Kemampuan Komunikasi Matematis Siswa Kelas Xi Sma PAB 8 Saentis. Jurnal Inspiratif, Vol. 3, No. 2 Agustus 2017. 


\section{Hasil Penelitian Siklus II}

Berdasarkan hasil tes kemampuan komunikasi matematis siswa untuk siklus
II diperoleh bahwa kemampuan komunikasi matematis siswa mengalami peningkatan.

Tabel 3 Dekripsi Tingkat Kemampuan Komunikasi Matematis Pada Siklus II

\begin{tabular}{|c|c|c|c|c|c|}
\hline No & $\begin{array}{c}\text { Tingkat } \\
\text { Penguasaan }\end{array}$ & $\begin{array}{c}\text { Skor } \\
\text { Standar }\end{array}$ & $\begin{array}{c}\text { Banyak } \\
\text { Siswa }\end{array}$ & $\begin{array}{c}\text { Persentase } \\
\text { Jumlah Siswa }\end{array}$ & Nilai Kualitatif \\
\hline 1. & $90 \%-100 \%$ & A & 4 & $13,33 \%$ & Sangat Tinggi \\
\hline 2. & $80 \%-89 \%$ & B & 6 & $20 \%$ & Tinggi \\
\hline 3. & $65 \%-79 \%$ & C & 16 & $53,33 \%$ & Sedang \\
\hline 4. & $55 \%-64 \%$ & D & 3 & $10 \%$ & Rendah \\
\hline 5. & $\leq 54 \%$ & E & 1 & $3,33 \%$ & Sangat Rendah \\
\hline
\end{tabular}

Diagram batang persentase tingkat ketuntasan tes kemampuan komunikasi

matematis II pada pokok bahasan Program Linier :

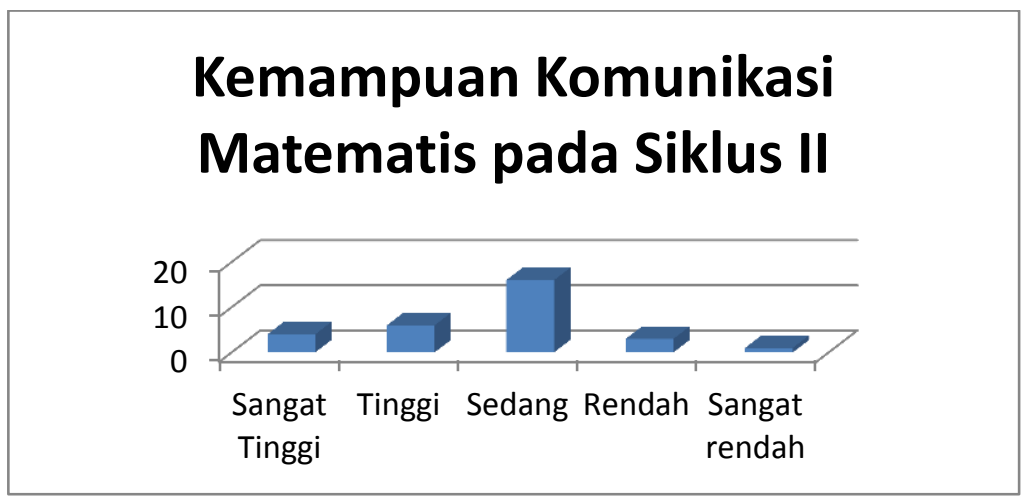

\section{Gambar 3 Tingkat Kemampuan Komunikasi Matematis \\ Siswa Pada Siklus II}

Dari diagram diatas diperoleh bahwa siswa yang memiliki predikat A sebanyak 4 siswa, siswa yang memiliki predikat B sebanyak 6 siswa, siswa yang memiliki predikat $\mathrm{C}$ sebanyak 16 siswa, siswa yang memiliki predikat D sebanyak 3 siswa, siswa yang memiliki predikat $\mathrm{E}$ sebanyak 1 siswa. Dari hasil tersebut terlihat bahwa 26 dari 30 orang siswa $(86,67 \%)$ telah mencapai standar kemampuan penalaran matematis yang ditargetkan, yaitu siswa yang memperoleh nilai $\geq 65$ dengan kategori minimal sedang. Itu artinya standar keberhasilan penelitian sudah tercapai.

Togi, Mei Lastiar Nababan. Implementasi Model Pembelajaran Advance Organizer Berbantuan Macromedia Flash Untuk Meningkatkan Kemampuan Komunikasi Matematis Siswa Kelas Xi Sma PAB 8 Saentis. Jurnal Inspiratif, Vol. 3, No. 2 Agustus 2017. 
Tabel 4 Deskripsi Hasil Rata-rata Kemampuan Komunikasi Siswa Tiap Tes

\begin{tabular}{|l|c|c|c|}
\hline & Tes Awal & Siklus I & Siklus II \\
\hline $\begin{array}{l}\text { Rata-rata kemampuan } \\
\text { komunikasi matematis } \\
\text { siswa }\end{array}$ & $\mathbf{4 5 , 8 3}$ & $\mathbf{6 4 , 1 4}$ & $\mathbf{7 8 , 7 5}$ \\
\hline $\begin{array}{l}\text { Persentase siswa yang } \\
\text { mencapai KKM }\end{array}$ & $\mathbf{2 6 , 6 7 \%}$ & $40 \%$ & $\mathbf{8 6 , 6 7 \%}$ \\
\hline Observasi Guru & - & $\mathbf{3 , 4 8}$ & $\mathbf{3 , 6 7}$ \\
\hline
\end{tabular}

Dengan demikian berdasarkan hasil tes kemampuan komunikasi matematis siswa II pada siklus II, diperoleh bahwa nilai rata-rata kemampuan komunikasi mencapai 75, dengan tingkat ketuntasan 86,67 siswa sudah mencapai KKM. Karena $86,67 \%$ siswa memperoleh kategori tinggi untuk kemampuan komunikasi matematis siswa (ketuntasan klasikal tercapai), dan tingkat kemampuan guru dalam mengelola pembelajaran dalam kategori baik, maka guru tidak perlu melanjutkan ke siklus berikutnya. Dengan demikian berdasarkan hasil observasi dan tes kemampuan komunikasi matematis siswa dapat disimpulkan bahwa penerapan model advance organizer berbantuan macromedia flash dalam pembelajaran matematika dapat meningkatkan kemampuan komunikasi matemematis siswa pada materi program linier kelas XI MIA 3 SMA PAB 8 Saentis.

\section{Kesimpulan}

Berdasarkan hasil penelitian dan pembahasan yang dijelaskan diperoleh kesimpulan sebagai berikut:
Kemampuan komunikasi matematis yang diajarakan dengan menerapkan model advance organizer berbantuan macromedia flash dilihat dari siklus I ratarata kemampuan komunikasi siswa diperoleh 64,14. Adapun tingkat kemampuan komunikasi matematis yang mencapai kategori sangat tinggi sebanyak 3 orang siswa dengan persentase $10 \%$, kategori tinggi sebanyak 3 orang siswa dengan persentase $10 \%$, kategori sedang sebanyak 9 orang siswa dengan persentase $30 \%$, kategori rendah sebanyak 7 orang siswa dengan persentase $23,33 \%$, kategori sangat kurang sebanyak 8 orang siswa dengan persentase $26,67 \%$. Jika ditinjau per indikator pada siklus I maka indikator pertama menjelaskan pernyataan matematika siswa dalam kategori baik $13,33 \%$, indikator kedua menulis (mendefenisikan) sebanyak 46,67\% dan indikator ketiga representasi sebanyak 79,97\%. Selanjutnya setelah diadakan perbaikan tindakan pada siklus II diperoleh rata-rata kemampuan komunikasi matematis siswa adala 78,75. Pada kategori sangat tinggi sebanyak 4 orang siswa dengan persentase $13,33 \%$, kategori tinggi sebanyak 6 orang siswa dengan persentase $20 \%$, kategori sedang

Togi, Mei Lastiar Nababan. Implementasi Model Pembelajaran Advance Organizer Berbantuan Macromedia Flash Untuk Meningkatkan Kemampuan Komunikasi Matematis Siswa Kelas Xi Sma PAB 8 Saentis. Jurnal Inspiratif, Vol. 3, No. 2 Agustus 2017. 
sebanyak 16 orang siswa dengan persentase 53,33\%, kategori rendah sebanyak 3 orang siswa dengan persentase $10 \%$, dan kategori sangat kurang sebanyak 1 orang siswa dengan persentase $3,33 \%$. Pada siklus II indikator pertama menjelaskan pernyataan matematika siswa dalam kategori baik 46,67\%, indikator kedua menulis (mendefenisikan) sebanyak $76,6 \%$ dan indikator ketiga representasi sebanyak $73,34 \%$. Dari data yang diperoleh di atas, maka dapat disimpulkan bahwa terjadi peningkatan kemampuan komunikasi matematis dari siklus I ke siklus II. Hal ini disebabkan karena adanya perbaikan tindakan yang diberikan. Ini berarti model pembelajaran advance organizer berbantuan macromedia flash dapat meningkatkan kemampuan komunikasi matematis siswa pada materi program linier di kelas XI MIA 3 SMA PAB 8 Saentis.

\section{Saran}

Berdasarkan hasil penelitian, pembahasan serta kesimpulan, maka peneliti memberikan beberapa saran sebagai berikut:

1. Kepada guru matematika khususnya guru matematika SMA PAB 8 Saentis disarankan menerapkan model advance organizer berbantuan macromedia flash sebagai alternatif untuk meningkatkan kemampuan komunikasi matematis siswa, khususnya pada materi program linier dan perlu dicoba untuk materi yang lain.

2. Guru sebaiknya berupaya untuk selalu melibatkan siswa untuk lebih aktif dan membuat suasana yang menyenangkan dalam proses belajar mengajar sehingga siswa tertarik dan termotivasi dalam belajar serta dapat mengkondisikan siswa dalam keadaan nyaman dan siap untuk belajar, karena kondisi yang nyaman dapat menciptakan suasana yang efektif dan efisien untuk belajar.

3. Kepada siswa khususnya siswa SMA PAB 8 Saentis diharapkan untuk lebih aktif dalam proses pembelajaran, lebih banyak berlatih menyelesaikan soalsoal dan lebih berani untuk mengungkapkan ide dan pendapat saat berdiskusi.

4. Bagi peneliti lain yang ingin melakukan penelitian sejenis dapat melakukan penelitian lebih lanjut mengenai penggunaan model advance organizer berbantuan macromedia flash terhadap peningkatan kemampuan belajar lainnya serta penerapannya pada pokok bahasan yang berbeda.

\section{DAFTAR PUSTAKA}
Abdurrahman, Mulyono. 2003. Pendidikan Bagi Anak Berkesulitan Belajar. Jakarta: Rineka Cipta

Ansari, 2009. Komunikasi Matematis. Banda Aceh. Penerbit Pena

Ansari, 2016. Komunikasi Matematis. Banda Aceh. Penerbit Pena

Togi, Mei Lastiar Nababan. Implementasi Model Pembelajaran Advance Organizer Berbantuan Macromedia Flash Untuk Meningkatkan Kemampuan Komunikasi Matematis Siswa Kelas Xi Sma PAB 8 Saentis. Jurnal Inspiratif, Vol. 3, No. 2 Agustus 2017. 
Arikunto, dkk, 2015. Penelitian Tindakan Kelas. Jakarta: Bumi Aksara

Aziz, 2010. Penerapan Pembelajaran Matematika dengan Strategi Student Team Heroic untuk Meningkatkan Kemampuan Komunikasi Matematis Siswa. Bandung: FMIPA UPI

Dahar, R.W, 2006. Teori-teori Belajar dan Pembelajaran. Bandung: Erlangga

Huda, Miftahul, 2014. Model-model Pengajaran dan Pembelajaran. Yogyakarta. Pustaka Pelajar

MADCOMS, 2006. Mahir Dalam 7 Hari Macromedia Flash 8. Madiun. CV Andi Offset

Sihombing, W.L, 2013. Telaah Kurikulum Matematika Sekolah. Medan. FMIPA Universitas Negeri Medan

Simanjuntuk, M \& Surya, E, 2015. Peningkatan Kemampuan Representasi Dan Komunikasi Matematis Siswa Smp Pada Materi Transformasi Dengan Strategi Think-Talk-Write (Ttw) Berbantuan Kartu Domin.Jurnal Paradikma, Vol.8 No.1

Togi, Mei Lastiar Nababan. Implementasi Model Pembelajaran Advance Organizer Berbantuan Macromedia Flash Untuk Meningkatkan Kemampuan Komunikasi Matematis Siswa Kelas Xi Sma PAB 8 Saentis. Jurnal Inspiratif, Vol. 3, No. 2 Agustus 2017. 